\title{
Student Learning Outcomes in Addictive and Addictive Subject Using Inquiry and Project Models
}

\author{
Sri Hendra Suryani ${ }^{1 *}$, Suryajaya ${ }^{2}$, Arif Sholahuddin ${ }^{3}$ \\ ${ }^{1}$ Masters Program of Natural Sciences Teaching, Lambung Mangkurat University, Banjarmasin, Indonesia \\ ${ }^{2}$ Department of Physics, Faculty of Mathematics and Natural Science, Lambung Mangkurat University, Indonesia \\ ${ }^{3}$ Department of Chemistry Education, Faculty of Teacher Training and Education, Lambung Mangkurat University, Indonesia
}

DOI: $10.36348 /$ jaep.2020.v04i06.007

| Received: 30.05 .2020 | Accepted: 09.06.2020 | Published: 12.06.2020

*Corresponding author: Sri Hendra Suryani

\section{Abstract}

Indonesia's learning education quality is expected to be better, especially natural science learning. Its improvement process is begun by paying attention to students' necessities and their learning characteristics in a field. Natural science learning that is based by curiosities will arise better learning experience, so it is appropriate if a teacher applies inquiry base model and project base model. The purpose of this research is intended to understand differences of students' learning outcomes between a group of students that learns using inquiry learning model and project learning model. The kind of this research is quasi experimental design. The population of this research is the students of eight grade of SMP Negeri 10 Banjarbaru and its sample consists of eight grade of A as a group that is applied by inquiry learning model, eight grade of B as a group that is applied by project learning model and eight grade of $\mathrm{C}$ as a group that is applied by conventional learning model which its function is as a controlling group. The found data were analyzed by anova examination. Based on the results of the research, there are found the significant differences of outcomes learning between the students who are taught using conventional model and who are taught using inquiri model, and so the students who are taught using conventional model and Project model, as well. But there are not significant differences of learning outcomes between the students who are taught using inquiri model and Project model.

Keywords: Inquiry, project, learning outcomes.

Copyright @ 2020: This is an open-access article distributed under the terms of the Creative Commons Attribution license which permits unrestricted use, distribution, and reproduction in any medium for non-commercial use (NonCommercial, or CC-BY-NC) provided the original author and sources are credited.

\section{INTRODUCTION}

The principle of the learning process experienced by humans lasts throughout life, meaning a continuous process, which never stops and is not limited to the walls of the classroom. This is because during his lifetime, humans will always face problems and obstacles in achieving goals. Through the learning process, students will gain awareness and ability to learn to overcome problems and obstacles. The learning process of science is focused on growing students' thinking abilities, namely the ability to formulate hypotheses. The hypothesis will stimulate students to think more critically and in more detail. However, this ability to think will not be able to develop in science learning without experimentation. Learning science in Indonesia is still dominated by the view that scientific knowledge is a collection of facts that must be memorized and is still centered on the teacher as a source of knowledge.
According to Wisudawati and Sulistyowati [1], the science learning process is expected to improve the quality of education in Indonesia. The learning process of Natural Sciences has not been able to touch on the realm of meaningfulness of the concepts obtained in school/college. Furthermore Tabany [2] said that in a more complex sense, learning is essentially the conscious effort of a teacher to learn his students (directing student interaction with other learning resources) in order to achieve the expected goals. This is where the teacher's role becomes very important so that learning becomes useful, meaningful for students.

Bruner's learning theory suggests that the learning process occurs through stages: a) manipulation of direct objects (enactive); b) representative image (iconic); c) symbolic manipulation. Enactive stage is the activity of students to understand the environment through direct observation of reality. The iconic stage occurs when students observe reality not directly, but through secondary sources, for example through pictures or writing. The symbolic stage occurs when 
students make abstractions in the form of theory, interpretation, analysis of reality that has been observed and experienced [3]. The implication of Bruner's theory in the learning process is exposing children to a confusing situation or a problem. With his experience the child will try to adjust or reorganize the structures of his ideas in order to achieve a balance in the mind of the curiosity.

Based on observations in the field the student's science learning outcomes are still low. The average value of natural science of students who enter SMP 10 Banjarbaru in 2017/2018 is 45.53. This value is far from the KKM (Minimum Mastery Criteria) that applies in SMP Negeri 10 Banjarbaru. There are many things that cause low student learning outcomes. In general, internal factors of students that cause low learning outcomes are lack of interest and motivation to learn. And external factors causing the low learning outcomes include, lack of learning facilities and infrastructure, lack of teacher's ability to provide meaningful learning that is able to build and increase student motivation in a subject area. With the increased interest and great motivation it is hoped that it can develop the potential of students to prepare them to become a generation that has ability and high competitiveness in the future. Most teachers do not yet have the ability to apply learning models that can arouse the motivation and activity of students' critical thinking skills in the classroom which ultimately can improve student learning outcomes.

Since humans were born into the world, humans have the urge to find their own knowledge. Curiosity about the surrounding nature is a human nature since he was born into the world. Since childhood, humans have the desire to know everything through the senses of sight, hearing, taste and other senses. Until adulthood, human curiosity continuously develops by using the brain and mind. Based on this, a learning model known as inquiry or discovery learning was developed.

The characteristics of inquiry learning are fun, not boring, passionate learning, integrated learning, using various sources, active students, critical students, and creative teachers. The characteristics of junior high school students are less interested in learning in the form of theory let alone delivered in a monotonous lecture. If observed they prefer to learn by linking learning material to things in life around and discussing with their friends to solve problems. The fact shows that there are still many teachers who use conventional learning instead of contextual. There is a choice of learning strategies that are more aligned and empowering students, developing students' interests and experiences with inquiry learning models and projects.
Inquiry comes from the word to inquire which means to participate, or be involved in asking questions, seeking information, and conducting investigations. reflective thinking process. If thinking is the main goal of education, ways must be found to help individuals build that ability. In developing an attitude of inquiry in the classroom, the teacher has a critical role as a counselor, consultant and friend. The teacher must be able to guide and reflect on the learning experience.

Inquiry model is a learning in which the teacher guides students to do activities by giving initial questions and directing to a discussion. The teacher has an active role in determining the problem and the stages of its solution. The selection of the author's inquiry model is done with the consideration that the research will be conducted on the eighth grade students of junior high schools (SMP), where the level of cognitive development of students is still at a stage of transition from concrete operations to formal operations, and students are still inexperienced learning with the inquiry model. With this inquiry learning model students are expected to learn more oriented to the instructions from the teacher so students can understand the concepts of the lesson.

In addition to the inquiry learning model, another innovative learning model that is considered capable of improving student learning outcomes is the project learning model. Laviatan [4] states that projectbased learning is innovative learning that emphasizes complex activities with the aim of solving problems based on inquiry activities.

The project model (project based learning) is innovative student-centered learning (student centered) and places the teacher as a motivator and facilitator, where students are given the opportunity to work autonomously to construct their learning [2]. Because the topic of additives and addictive substances involves practicum observation activities in the laboratory, the project model can be used in problem solving on the topic of additives and addictive substances.

Inquiry learning model (inquiry) has 3 characteristics, namely: (1) Inquiry learning emphasizes student activities maximally to search and find; (2) All activities undertaken by students are directed to seek and find their own answers to something that is questioned, so that it is expected to foster an attitude of confidence (self belief); (3) The purpose of inquiry learning is to develop the ability to think systematically, logically, and critically, or develop intellectual abilities as part of mental processes [2].

While the project learning model according to Muliawati in Widyantini [5] there are 7 characteristics, namely: (1) The existence of complex problems or challenges raised to students, (2) Students design the process of solving problems or challenges proposed by 
using investigations, (3) Students learn and apply the skills and knowledge they have in various contexts when working on projects, (4) students work in cooperative teams as well as when discussing them with the teacher, (5) students practice the various skills needed for their adult lives and careers (how to allocate time, being a responsible individual, personal skills, learning through experience), (6) Students periodically reflect on the activities that have been carried out, (7) The student's final product in working on projects is evaluated.

\section{RESEARCH METHODS}

This research uses quasy experimental design. In this study there were 2 groups, namely the first group was treated with the inquiry model and the second group was treated with the project model. Both groups are assumed to be the same in all respects relevant and different in the use of learning models. The number of samples in this study around 150 students consisted of 6 different classes with the same grade level. Classes are selected by cluster random sampling after previously taking scores on the topic of the Food Digestion System and grouped according to the average value. The research instrument consisted of learning implementation instruments and data collection instruments. The learning implementation instrument is a set of learning such as syllabus, lesson plans, and student worksheets. The data collection instrument consisted of an instrument of cognitive learning achievement test results, an observation sheet, an implementation of the science process skills instrument. Data obtained from the results of the trial instrument were then analyzed to determine the validity, reliability, level of difficulty and distinguishing features of the questions. Data collection techniques in this study used two ways, namely the test and non-test. A test is a set of questions that must be answered in order to measure certain aspects. Non-test technique using a questionnaire and observation.

\section{RESEARCH RESULTS AND DISCUSSION Research Results Implementation of Teacher Learning}

The process of evaluating teacher activity involves 3 different classes with a total of 75 students and 2 observer teachers. Research activities carried out in the form of learning implementation. This process obtained data in the form of teacher activity observation evaluation sheets as shown in Table-1.

Table-1: Observation Results on the Implementation of Teacher Activities

\begin{tabular}{|l|l|l|l|l|l|l|}
\hline \multirow{2}{*}{ No } & Activity Phase & \multicolumn{3}{|l|}{ Percentage } & \multirow{2}{*}{ Mean } & \multirow{2}{*}{ Criteria } \\
\cline { 3 - 6 } & & P1 & $\mathbf{P 2}$ & $\mathbf{P 3}$ & & \\
\hline 1 & Teacher Activity in Inquiry Model & 77 & 88 & 91 & 85 & Very Good \\
\hline 2 & Teacher Activity in Project Based Model & 69 & 78 & 89 & 79 & Good \\
\hline 3 & Teacher Activity in Conventional Models & 57 & 69 & 77 & 70 & Good \\
\hline
\end{tabular}

\section{Practicality of Learning Tools}

The results of the observation sheet of student activity observation showed that each step of student activity 3 times face to face in general showed improvement and is presented in Table- 2 .

Table-2: Observation Results of Student Activities

\begin{tabular}{|l|l|l|l|l|}
\hline No & Student Activity & Conventional & $\begin{array}{l}\text { Project } \\
\text { Based }\end{array}$ & Inquiry \\
\hline 1 & Listen/pay attention to teacher's explanation. & $67 \%$ & $76 \%$ & $91 \%$ \\
\hline 2 & Read/understand teaching material. & $60 \%$ & $72 \%$ & $85 \%$ \\
\hline 3 & Work on the steps of the learning model in the worksheet. & $58 \%$ & $69 \%$ & $88 \%$ \\
\hline 4 & Using the learning flexibility provided & $67 \%$ & $81 \%$ & $88 \%$ \\
\hline 5 & $\begin{array}{l}\text { Actively involve yourself in the discussion process (asking } \\
\text { questions and expressing opinions) }\end{array}$ & $63 \%$ & $77 \%$ & $94 \%$ \\
\hline 6 & Present the results of the work & $64 \%$ & $76 \%$ & $91 \%$ \\
\hline 7 & Draw conclusions on subject matter & $64 \%$ & $74 \%$ & $89 \%$ \\
\hline & Average Percentage & $63 \%$ & $75 \%$ & $89 \%$ \\
\hline
\end{tabular}

\section{Difference in Student Learning Outcomes}

Student learning outcomes data obtained from the value of student answers in solving cognitive problems. This cognitive ability data was collected from the pre-test and post-test scores. Retrieval of cognitive abilities data collection was carried out before the learning activities by applying the lecture model, the inquiry model and the project model. For data collection the ability of posttest is carried out after the learning process by applying the lecture model, the inquiry model and the project model. The minimum completeness criteria set by the school is 65 . 
Table-3: Recapitulation of Learning Outcomes

\begin{tabular}{|l|l|l|l|l|l|l|l|l|}
\hline \multirow{2}{*}{ No } & \multirow{2}{*}{ Model } & Score & Completeness & Score & Completeness & Gain & N-gain & Category \\
& & Pre-test & & & & & & Progress \\
\hline 1 & Inquiry & 39.62 & $0 \%$ & 71.28 & $92 \%$ & 31.66 & 0.52 & Moderate \\
\hline 2 & Project & 39.60 & $4 \%$ & 67.87 & $64 \%$ & 28.27 & 0.46 & Moderate \\
\hline 3 & Conventional & 38.47 & $0 \%$ & 60.28 & $29 \%$ & 21.81 & 0.34 & Moderate \\
\hline
\end{tabular}

Category: High $\mathrm{G}=$ value of $\mathrm{g} \geq 0.70$; Medium $\mathrm{G}=$ value of $0.30 \geq \mathrm{g} \leq 0.70$; Low $\mathrm{G}=$ value of $\mathrm{g} \leq 0.30$

Note: KKM 65

\section{Descriptive analysis of $\mathrm{N}$-gain cognitive abilities of students}

This analysis aims to determine the extent to which students in each class gain cognitive abilities after participating in learning the topic of additives and addictive substances. $\mathrm{N}$-gain data is obtained from observations of lecture model classes, inquiry model classes and project model classes. The average $\mathrm{N}$-gain obtained is then interpreted according to the criteria proposed by Hake [6] as in Table-4.

Table-4: Interpretation of $\mathrm{N}$-gain cognitive abilities of the experimental class and the control class

\begin{tabular}{|l|l|l|}
\hline Class & Average N-gain & Category \\
\hline Conventional Learning Model & 0.34 & Moderate \\
\hline Project Learning Model & 0.46 & Moderate \\
\hline Inquiry Learning Model & 0.52 & Moderate \\
\hline
\end{tabular}

Classes that use inquiry learning models gain greater cognitive abilities than classes with project learning models and lecture learning. The inquiry learning model is considered better than the project learning model and lectures.

\section{Descriptive analysis of $\mathrm{N}$-gain cognitive abilities of students}

Inferential analysis aims to test the research hypothesis (H1) whether it is accepted or rejected. Data on cognitive abilities of students from the experimental class and the control class were tested using the ANOVA test to find out if there were significant differences in cognitive abilities before treatment using lecture models, inquiry models and project models on the topic of additives and addictive substances. Data on cognitive abilities of students from the two classes treated were also tested using the ANOVA test to find out whether there were significant differences in cognitive abilities. Before the ANOVA test is carried out, cognitive ability data is tested first with the normality and homogeneity tests.

\section{Normality Test}

The results of normality test calculations for student cognitive ability data with Liliefors test in the experimental class and the control class can be seen in Table-5.

Table-5: The normality test results of students cognitive abilities data

\begin{tabular}{|l|l|l|}
\hline Class & Sig. & Conclusion \\
\hline Conventional Learning Model & 0,484 & Normal Distributed Data \\
\hline Project Learning Model & 0,104 & Normal Distributed Data \\
\hline Inquiry Learning Model & 0,458 & Normal Distributed Data \\
\hline
\end{tabular}

\section{Homogeneity Test}

Homogeneity test results of cognitive abilities of students can be seen in Table-6.

Table-6: Homogeneity test results of cognitive learning outcomes of students

\begin{tabular}{|l|l|l|l|}
\hline Levene Statistic & $d f 1$ & df2 & Sig. \\
\hline 2.335 & 2 & 72 & 0.104 \\
\hline
\end{tabular}

Based on the results of homogeneity test data, the significance value of 0.104 is obtained, the value of which is greater than 0.05 . This can be interpreted that the price variance in each group is homogeneous. So the lecture learning model class, inquiry learning model and project learning model class have equivalent initial abilities.

\section{Comparative Test}

Anova test was carried out on the cognitive abilities data of the experimental class and control class students who had been tested for normality and homogeneity, with the results showing that both classes were normally distributed and homogeneous. ANOVA test results for students' cognitive data can be seen in Table-7. 
Table-7: Results of students cognitive abilities data

\begin{tabular}{|l|l|l|}
\hline Class & Sig. & Information \\
\cline { 1 - 1 } Lecture Learning Model & 0,000 & Significant \\
\cline { 1 - 1 } Inquiry Learning Model & & \\
\cline { 1 - 1 } Lecture Learning Model & 0,003 & Significant \\
\cline { 1 - 1 } Project Learning Model & & \\
\cline { 1 - 2 } Inquiry Learning Model & 0,176 & Significant \\
\cline { 1 - 1 } Project Learning Model & & \\
\hline
\end{tabular}

From table 4.17 it can be concluded that there are significant differences between the Lecture learning model and the Inquiry learning model, the Lecture learning model and the Project learning model. While the Inquiry learning model and the Project learning model show no significance. Between the Lecture learning model and the Inquiry learning model a significant value of 0,000 was obtained, the Lecture learning model and the Project learning model obtained a significant value of 0.003 . While the Inquiry learning model and the Project learning model obtained a significant value of 0.176 .

\section{RESEARCH DISCUSSION}

Inquiry learning is still quite foreign to students and teachers, however there is a strong urge to be able to do learning well. Even though the students were initially quite confused in adjusting to the new learning atmosphere, but after the learning went on for a while, the adjustment could easily be done. The implementation of the lesson plan cannot be separated from the teacher's role in managing learning. Bettencourt [7] argues that teaching means participation with learners in shaping knowledge, making meaning, seeking clarity, being critical, and making justifications. In line with this, Djamarah and Zain [8] suggested that in carrying out their duties as a teacher a teacher must master the material being taught and the models used in learning. In addition, teachers are also able to utilize components of learning activities that include goals, teaching activities, learning materials, methods, tools and materials optimally. This is supported by Shamsudin et al., [9] in their research teaching strategies of science using inquiry models based on science education states that when teaching with inquiry models, teacher skills and knowledge are also increasingly developing in classroom management, wiser and improve teacher communication skills in terms of facilitating students to achieve more effective results.

Based on the analysis of the implementation of lesson plans, it can be seen that the learning steps taken by the teacher are in accordance with the syntax of the inquiry model and the syntax of the project model. The average implementation of the RPP achieved by almost all components was carried out very well. This excellent percentage of RPP implementation also shows that teachers in learning activities can implement the principles expressed by Wintour, J. A. and Wintour, J. M. in Drost [10] that teaching science should meet four criteria, namely (1) interesting, so students can feel the pleasure of science; (2) more emphasis on process teaching rather than material; (3) encourage students to look for reading materials related to science. Thus it means that the natural learning model of inquiry model, project model and lecture model are eligible to be used.

Overall from the three learning models it can be concluded that during the learning process takes place, student activities generally meet the good category and the most active is the inquiry learning model with a very good category.

The activeness of students is very prominent when they discuss, make observations, and conduct experiments. This will support them to get as much information about what they are learning. The activeness of these students shows to us that they enjoy learning with this model. This justifies the opinion of Hosnan [11] which states that one of the principles that must be applied to improve the quality of learning is to create learning conditions that are fun and challenging. Mustachfidoh's [12] research results also support this research that the application of inquiry models emphasizes the activities of students to find concepts and develop thinking skills systematically, logically and critically. The activeness of students in the class is also facilitated by how the teacher's activities in establishing the creation of good learning conditions during the learning process take place in the classroom.

Results the completion of the questionnaire was done after learning the inquiry models, projects, lectures that have been done in the field in the experimental class and the control class showed that students' responses to all statements at the level of $70 \%$ and above. The results above illustrate that in general students feel very interested during the science learning model of inquiry and project models. This shows that the subject matter of additives and addictive substances applied in the inquiry model and the project model shows a positive response.

The positive response was expressed by students through statements preferring science lessons with inquiry learning and project learning, having a high willingness to make good use of learning time, being easier to ask teachers or friends to understand the lesson, being able to master several scientific terms in the subject matter, can improve collaboration in groups, dare to express my opinion, can help friends who have 
difficulty understanding the lesson and can improve learning outcomes.

The inquiry learning model provides opportunities for students to be actively involved in their mental processes through observing and collecting data to draw conclusions. With the application of the inquiry model, students' interest in learning will be higher in learning science, high interest is motivation and encouragement for them to be more active in learning science so as to improve learning outcomes.

In addition, learning through inquiry will foster positive competition habits and cooperative attitudes among them to achieve the best results. This encouragement also led to effective learning, as expressed by Artana et al., [13] through his research using fifth grade elementary school students as research subjects stating that the inquiry learning model used affects the learning outcomes of Natural Sciences in terms of student learning interests. This increased interest also supports research conducted by Akinoglu [14] which states the implementation of project-based inquiry in science teaching can increase student interest which has an effect on improving learning outcomes.

\section{Comparison of Cognitive Learning Outcomes}

\section{1) Comparison of learning outcomes between students who are given learning with lecture models and inquiry models}

Based on the results of the study it was seen that the average value of student learning outcomes in the experimental class that applied learning using inquiry models, was higher than the learning outcomes of control class students who used the learning model of lectures (conventional). The average value of the experimental class was 71.28 while the control class was 60.28 . The number of students who completed the experimental class was $92 \%$ and the control class was $29 \%$. This shows that in the learning process by using the inquiry model the students completeness is higher than the learning model lecture, so the inquiry model is better than the lecture model. The statistical test also shows that the significance value between the lecture model and the inquiry model is $0,000(<0.05)$ which means that the inquiry learning model is better than the lecture learning model.

The results of the study in the experimental class, where student learning outcomes in the experimental class are better than the control class because the experimental class in the learning process uses the inquiry model. Inquiry model is a learning model that directs students to find knowledge, ideas and information through their own efforts [15]. According to Piaget [16] the Inquiry Model is "a model that prepares students in situations to carry out extensive experiments themselves to see what is happening, wants to do something, ask questions, and find their own answers, and correlates one finding with another, comparing what they find with what other students have found". By using the inquiry model, students can think and play an active role in the learning process and can experience their own learning experiences so that learning becomes more interesting and meaningful for students.

The results of the study in the control class, where the learning outcomes of the control class are lower than the experimental class because the model used is a lecture model in the form of lectures, discussions and questions and answers. When learning takes place more students become teacher listeners, record what is explained by the teacher and do the tasks given. Students are also more silent when the teacher gives questions about learning material. Such conditions make learning look less effective and cause students to understand learning material less than the maximum. Even so, the learning outcomes in the control class have better average values than before the research was conducted. This happens because students have a fairly good response in learning and students more easily understand the material being taught because it is not too difficult.

2) Differences in learning outcomes between students who are given learning with lecture models and project models

The average value of student learning outcomes in the experimental class that applied learning using the project model, is higher than the learning outcomes of control class students who use the lecture learning model. The average value of the experimental class was 67.87 while the control class was 60.28 . The number of students who completed the experimental class was $64 \%$ and the control class was $29 \%$. This shows that the learning process by using the project completeness model of students is higher than the lecture learning model, so the project model is better than the lecture model. And statistical tests also show that the significance value between the lecture model and the project model is $0.003(<0.05)$, which means the project learning model is better than the lecture learning model.

The PjBL learning model is project-based learning that actively engages students in designing learning objectives to produce tangible products or projects. Projects created by students provide real learning and also encourage a variety of student abilities. In PjBL it is not only technical knowledge or problems that students get, but also practical skills such as overcoming incomplete and inaccurate information and determining the goals of self-learning and group cooperation. Students are required to be trained to analyze problems and then explore, gather information, interpret and evaluate work on projects related to the problem being examined [3]. PjBL learning makes students more active in thinking in solving problems and creating solutions to existing problems. The final 
result of this learning model is a project. As explained by Abidin [17] that project appraisal can be used to find out understanding, ability, applying, ability to investigate, and ability to clearly inform something.

In the experimental class learning is given using the Project Based Learning model and there is a significant increase compared to the control class using the lecture model. It is proven that project-based learning can improve student learning outcomes, because students are given the opportunity to develop ideas and learn to find solutions to real problems [18]. The Project Based Learning model is a learning model that focuses on the main (central) concepts and principles of a discipline, engages students in problem solving activities and other meaningful tasks, gives students the opportunity to work autonomously to construct their own learning, and culminating in producing valuable and realistic student work products [19]. By using the Project Based Learning learning model, students are expected to be able to understand the concept of material well and can develop their mindset in making a project that can produce a product that can be used in life.

\section{3) Differences in learning outcomes between students who are given learning with the Inquiry Model and the Project Model \\ The average value of student learning} outcomes in the experimental class that applied learning using inquiry models, is higher than the learning outcomes of control class students who use project learning models. The average value of the experimental class was 71.28 while the project class was 67.87 . The number of students who completed the experimental class using the inquiry model was $92 \%$ and the class using the project model was $64 \%$. This shows that in the learning process by using a student inquiry model completeness is higher than the learning model project.

Inquiry and Project are learning models aimed at making students more active in learning. Active in terms of thinking, analyzing and breaking things up. Both of these learning models lead students to think differently. Inquiry forces students to think critically to formulate existing problems. While the Project requires students to create a project based on the material being taught. However, based on the results of statistical tests on these two learning models, the results show that between Inquiry and Project learning models have a significance value of $0.176(>0.05)$ so that it can be concluded that there is no difference between Inquiry learning models and Project learning models.

Based on the results of the study showed that cognitive learning outcomes in the experimental class were seen to have a significant increase between the pretest and posttest compared to the control class. That means the use of inquiry-based learning model that is centered on students has been able to improve cognitive learning outcomes rather than lecture learning that relies on the lecture model and is teacher-centered. The existence of an increase in cognitive learning outcomes is the result of increasing students' understanding of concepts influenced by an interesting learning atmosphere, encouraging students to get better results, also helping students understand abstract concepts because students can see directly the events they learned so that the results of understanding concepts students can improve.

This is in line with research conducted by Anggareni et al., [20] who conducted research on the implementation of inquiry learning strategies for seventh grade students of science subject in the concept of ecosystems. In the results of his research, Anggareni, et al stated that the implementation of inquiry learning strategies can improve critical thinking skills and understanding IPA concepts of junior high school students. The results of Suparsorn's study 2012 also state that inquiry learning conducted on chemistry subjects can improve students' understanding of the concepts of extraction and refining. Another study, Arslan and Ogan [21] stated that inquiry models are effective when used in science learning classes, where students are able to improve their understanding of science concepts.

The learning model that is considered capable of developing student learning outcomes and understanding of concepts is the inquiry learning model. The inquiry learning model according to Colburn not only dictates concepts, but encourages student learning experiences to understand scientific concepts, which can provide deeper insights, making concepts longer remembered and meaningful for students. In the inquiry model, students are guided by the teacher in understanding concepts through a series of experiments [22]. The inquiry model in its implementation further optimizes the teacher's instructions to students so that the learning process will be faster and easier to understand. Thus, students more easily understand the material being taught.

One of the learning models in the 2013 curriculum that provides opportunities for students to develop problem-solving skills is the project-based learning model $(\mathrm{PjBL})$ or the project-based learning model. Project work contains complex tasks based on very challenging problems, and requires students to design, solve problems and make decisions. The use of project learning models requires student independence in learning. So that in practice there may be confusion for students who are accustomed to getting direction/guidance in the learning process. Projectbased learning is learning that uses to guide projects/activities as a medium and uses problems as a first step in gathering and integrating new knowledge based on students' experiences in real activities. Projectbased learning is learning that guides student creativity. 
According to Trianto [23] states that: The learning model of project based learning is a model of activities in different classes than usual. Project-based activities are long-term, interdisciplinary, student-centered and related to real-world problems.

\section{CONCLUSION}

1. There are differences in learning outcomes between students learning with lecture models and inquiry models on the topic of additives and addictive substances.

2. There are differences in learning outcomes between students learning with lecture models and project models on the topic of additives and addictive substances.

3. There is no difference in learning outcomes between students learning with inquiry models and project models on the topic of additives and addictive substances.

\section{REFERENCES}

1. Wisudawati, A. W., \& dan Sulistyowati, E. (2014). Metodologi Pembelajaran IPA. Jakarta: PT. Bumi Aksara.

2. Tabany, T. I. B. (2014). Mendesain Model Pembelajaran Inovatif, Progresif, Dan Kontekstual. Jakarta: Prenadamedia Group.

3. Sani, R. A. (2014). Inovasi Pembelajaran. Jakarta: PT. Bumi Aksara.

4. Laviatan, T. (2008). InnovativeTeachingand Assessment Method: QBIand Project BasedLearning. MathematicsEducati on ResearchJournal, 10(2):105-116.

5. Widyantini, T. (2014). Penerapan Model Project Based Learning (Model Pembelajaran Berbasis Proyek) dalam Materi Pola Bilangan Kelas VII. Yogyakarta: PPPPTK Matematika.

6. Hake, R. R. (1999). Analyzing Change/Gain Scores. AREA-D American Education Research Association's Devision. D, Measurement and Research Methodology.

7. Suparno, P. (1997). Filsafat Konstruktivisme dalam Pendidikan: Yogyakarta: Kanisius.

8. Djamarah, B., \& Zain, A. (1996). Pengelolaan Belajar. Jakarta: Rajawali Pers.

9. Shamsudin, M. Z. (2013). Design and Implementation Of Temperature Monitoring Using ZigBee Wireless Technology.

10. Drost, Y. C., Van Lenteren, J. C., \& Van Roermund, H. J. W. (1998). Life-history parameters of different biotypes of Bemisia tabaci (Hemiptera: Aleyrodidae) in relation to temperature and host plant: a selective review. Bulletin of Entomological Research, 88(3), 219-230.

11. Hosnan, M. (2014). Pendekatan saintifik dan kontekstual dalam pembelajaran abad 21: Kunci sukses implementasi kurikulum 2013. Ghalia Indonesia.

12. Mustachfidoh, M., Swasta, I. J., \& Widiyanti, N. M. (2013). Pengaruh Model Pembelajaran Inkuiri Terhadap Prestasi Belajar Biologi Ditinjau Dari Inteligensi Siswa SMA Negeri 1 Srono. Jurnal Pendidikan IPA Ganesha, 3(1), 121096.

13. Artana, D., Lavigne, P., Guardarucci, I., Puig, J., \& Susmel, N. (2015). El sistema tributario argentino. Análisis y evaluación de propuestas para reformarlo. Fundación de Investigaciones Económicas Latinoamericanas

(FIEL).

Documento de Trabajo, (123).

14. Akinoglu, O. (2008). Primary Education Curriculum Reforms in Turkey. Online Submission, 3(2), 195-199.

15. Yogica, R., Lufri, L., \& Sumarmin, R. (2014). Efektifitas Modul Bergambar Disertai LKS Berorientasi Konstruktivistik Terhadap Proses dan Aktivitas Belajar Siswa Dalam Pembelajaran Biologi SMA. Penelitian Pendidikan, 5(1).

16. Mulyasa, E. (2009). Implementasi KTSP Kemandirian guru dan kepala sekolah. Jakarta: Bumi Aksara.

17. Abidin, Z., Davoren, M., Naughton, L., Gibbons, O., Nulty, A., \& Kennedy, H. G. (2013). Susceptibility (risk and protective) factors for inpatient violence and self-harm: prospective study of structured professional judgement instruments START and SAPROF, DUNDRUM-3 and DUNDRUM-4 in forensic mental health services. BMC psychiatry, 13(1), 197.

18. Rahmawati, D. (2011). Pengaruh model pemeblajaran berbasis proyek terhadap hasil belajar fisika siswa; studi quasi eksperimen di SMPN 48 Jakarta.

19. Ngalimun. (2013). Strategi dan Model Pembelajaran. Banjarmasin: Aswaja Pressindo.

20. Anggareni, N. W., Ristiati, N. P., \& Widiyanti, N. L. P. M. (2013). Implementasi strategi pembelajaran inkuiri terhadap kemampuan berpikir kritis dan pemahaman konsep IPA siswa SMP. Jurnal Pendidikan dan Pembelajaran IPA Indonesia, 3(1).

21. Ogan-Bekiroğlu, F., \& Arslan, A. (2014). Examination of the effects of model-based inquiry on students' outcomes: Scientific process skills and conceptual knowledge. Procedia-Social and Behavioral Sciences, 141, 1187-1191.

22. Joyce, B., Weil, M., \& dan Calhoun, E. (2000). Model of Teaching Sixth Edition. United States of America: Allyn \& Bacon A Pearson Education Company.

23. Trianto, I. B. (2014). Mendesain model pembelajaran inovatif, progresif, dan kontekstual. Jakarta: Prenadamedia Group. 